\title{
ZARZĄDZANIE W DZIAŁACH ZWIĄZANYCH Z OBRONNOŚCIĄ PAŃSTWA WEDLUG OPINII STUDENTÓW BEZPIECZEŃSTWA
}

\begin{abstract}
Współczesne zarządzanie państwem poprzez jego struktury w warunkach niepewności geopolitycznej i cyklów koniunkturalnych gospodarki, przy wykorzystaniu zasobów ludzkich jest wyzwaniem dla kierujących elit. Kluczowym czynnikiem budowania nowoczesnego państwa są kadry jako jego nierozłączny element. Jak przewidują specjaliści z tej dziedziny należy przewidywać możliwość rozwiązywania problemów społeczno-politycznych i gospodarczych, które mogą jeszcze wystąpić, a których przebieg i generujące się przy tym potencjalne zagrożenia są na dzień dzisiejszy jeszcze trudne do opisania, a tym bardziej do zdefiniowania. Wszystko to przy rodzących się nowych zagrożeniach w sferze cyberprzestrzeni jako dominujących w obecnych i przyszłych czasach. W historii ciągłości państwa powstało wiele aktów normatywnych, które mają za zadanie opisać ramy jego funkcjonowania - cały czas ulegają one procesowi ewaluacji. W telegraficznym skrócie zostaną przedstawione akty prawne regulujące badany problem ze szczególnym uwzględnieniem resortów „siłowych” związanych bezpośrednio z bezpieczeństwem państwa. Zostaną opisane formy językowe, zwroty pojęciowe (decyzja, zarządzenie, rozkaz, polecenie służbowe), nie wszystkie z nich są typowe tylko dla tych resortów. Bezpieczeństwo państwa tworzy cała gospodarka narodowa. Artykuł ma na celu encyklopedyczne przedstawienie tych pojęć tylko ze względu na rozmiary publikacji, jednakże na tyle dokładnie, aby poznać cel artykułu. Natomiast ich zrozumienie zostanie poddane badaniu na populacji studentów studiujących kierunki bezpieczeństwa. Jak przewidują autorzy wyniki badań mogą posłużyć potwierdzeniu słuszności planów nauczania lub ich modyfikacji z zastosowaniem innowacyjnych rozwiązań.
\end{abstract}

Keywords: zarządzanie, bezpieczeństwo, resorty siłowe.

\footnotetext{
${ }^{1}$ Dr Hanna Sommer, Katedra Nauk Humanistycznych, Wydział Zarządzania, Politechnika Rzeszowska, Al. Powstańców Warszawy 8, 35-959 Rzeszów, autor korespondencyjny; e-mail: hansom@ @rz. edu.pl.

Hanna Sommer, PhD, Department of Humanities, Faculty of Management, Rzeszów University of Technology, Al. Powstańców Warszawy 8, 35-959 Rzeszów, corresponding author; e-mail: hansom@prz.edu.pl.

2 Dr inż. Grzegorz Zakrzewski, Wyższa Szkoła Bezpieczeństwa z siedzibą w Poznaniu, ul. Marynarki Polskiej 15, 80-557 Gdańsk; e-mail: grzegorz.zakrzewski@wsb.net.pl.

Grzegorz Zakrzewski, PhD Eng., Wyższa Szkoła Bezpieczeństwa with its registered office in Poznań, ul. Marynarki Polskiej 15, 80-557 Gdańsk; e-mail: grzegorz.zakrzewski@wsb.net.pl.
} 


\section{WPROWADZENIE}

Jeśli sięgnąć w pisaną cywilizację ludzkości, to widać, że jej twórcy od zarania dziejów zajmowali się procesem zarządzania, nie zawsze zwłaszcza w pierwszym okresie spisując te zasady. Proces kierowania wspólnotami plemiennymi wymuszał na ich przywódcach uwzględnienie chociażby czynników siedliskowych. Współczesna nauka zwana ekologią najprościej siedlisko definiuje jako miejsce o określonym zespole czynników abiotycznych, tj. klimatycznych i glebowych na danej szerokości geograficznej, który zasiedla dany organizm lub biocenoza. Biocenoza natomiast definiowana jest jako część żywa ekosystemu. Rozszerzając definicję można ponad wszelką wątpliwość stwierdzić, że jest to zespół wszystkich żywych gatunków fauny i flory powiązanych ze sobą, przez który płynie strumień energii. Za człowieka pracę tę wykonała matka natura w procesie fotosyntezy, którą opisuje reakcja chemiczna:

$$
6 \mathrm{CO}_{2}+6 \mathrm{H}_{2} \mathrm{O} \rightarrow \text { energia } \mathrm{C}_{6} \mathrm{H}_{12} \mathrm{O}_{6}+6 \mathrm{O}_{2} .
$$

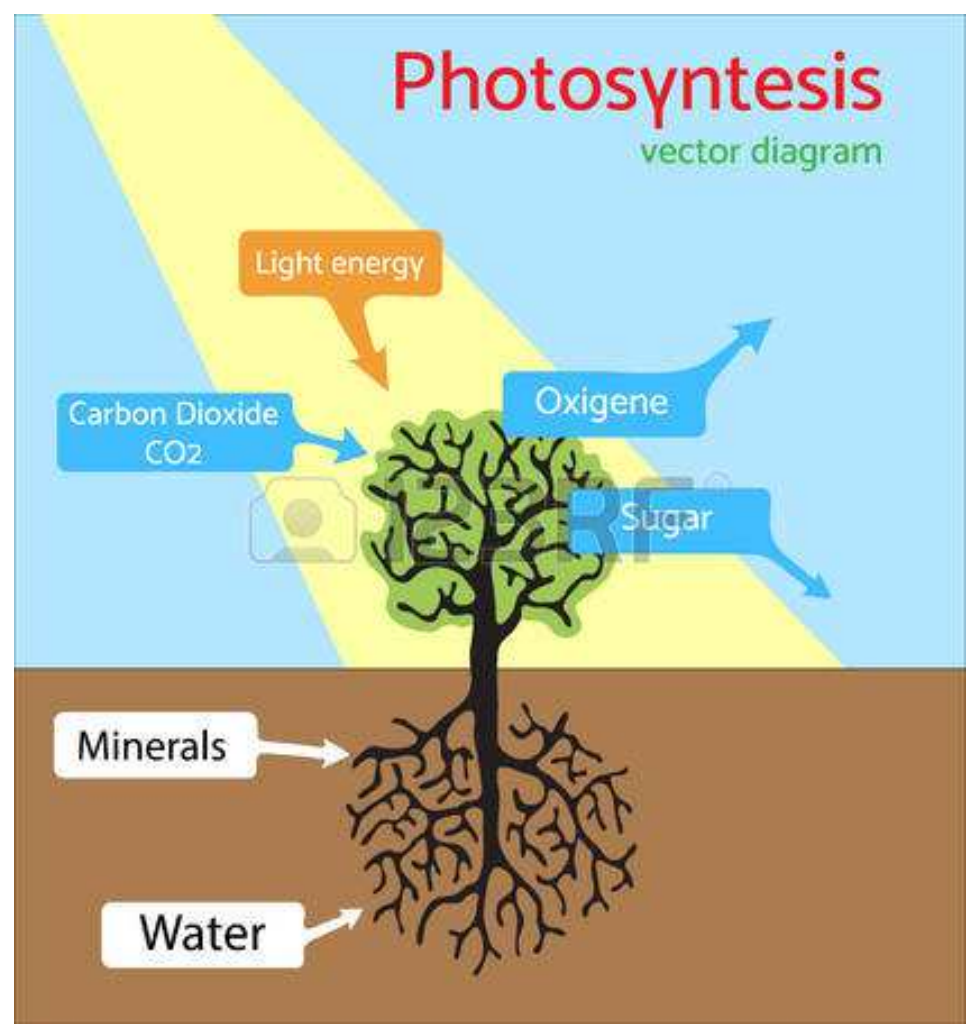

Rys. 1. Pierwowzór idealnego zarządzania

Źródło: https://www.google.pl/search?q=proces+fotosyntezy\&client=firefox-b-ab\&dcr=0\&tbm= isch\&source=iu\&ictx=1\&fir=FWaLRfEIgA7uJM $\% 253 \mathrm{~A} \% 252 \mathrm{Cs} 8 \mathrm{jDVU}$ DIS0wDrzM $\% 252 \mathrm{C}_{-}$ \&usg=_juzK4Q2HJPF-8AVE0XbAmXdfGhs\%3D\&sa=X\&ved=0ahUKEwjv4uGHo4TYAhUGU1AKHfCQCuoQ9QEITDAH\#imgrc=xvgH9gFg7HAtHM (dostęp: 12.12.2017 r.). 
Rysunek 1 przedstawia pierwowzór procesu idealnego zarządzania, jaki występuje w przyrodzie. Ziemia jako planeta nie wytwarza odpadów. Niektóre jednak wytworzone związki chemiczno-fizyczne wytworzone w toku planowej (np. industrializacja, konflikty zbrojne wnoszące zmiany w siedlisku poprzez zastosowanie broni masowego rażenia: atomowej, chemicznej i biologicznej, broni geofizycznych - zmieniających naturalny porządek poprzez: zwiększenie opadów atmosferycznych, wywołanie sztucznych zmian w polach fizycznych Ziemi jako planety) lub nieplanowej (działania destrukcyjne sił przyrody: powodzie tsunami, wybuchy wulkanów) działalności człowieka w wyniku zarządzania zasobami naturalnymi potrzebują jedynie czasu, aby zmienić się w nietoksyczne i nieszkodliwe. Od tej pory wszystko jest podobne do pierwowzoru i stara się naśladować jedynie tę doskonałość. Człowiek jako najwyższy drapieżnik w drabinie troficznej zaczął podporządkowywać sobie przyrodę, tu rozumianą jako środowisko naturalne. To środowisko naturalne zaczął utechniczniać wprowadzając w krajobraz swoje budowle i rozwiązania techniczno-organizacyjne sprzyjające rozwojowi cywilizacji.

Nawiąując do tematu prowadzonych dociekań naukowych zmieniać można środowisko stosując wszelkie metody i techniki zarządcze zarówno w czasie pokoju jak i wojny tworząc podwaliny pod współczesne zarządzanie. Sokrates wypowiedział się 400 lat p.n.e. na temat praktyk i koncepcji zarządzania, podobnie Platon 350 lat p.n.e. opisał specjalizację pracy. Starożytni Grecy według opisanych zasad zarządzali miastami - państwami. Podobnie na ten temat wypowiadali się starożytni Sumerowie, Babilończycy, Chińczycy, Rzymianie i Egipcjanie, którzy wykorzystali praktyki zarządzania przy budowie piramid. Ze względu na objętość artykułu nie zostanie tutaj omówiona współczesna nauka o szeroko definiowanym zarządzaniu.

\section{DOKUMENTY REGULUJĄCE ZARZĄDZANIE BEZPIECZEŃSTWEM PAŃSTWA}

W dniu 12 września 1989 r. Sejm RP zatwierdził skład rządu, na którego czele stanął Tadeusz Mazowiecki. Powołanie tego rządu było konsekwencją dwóch ważnych wydarzeń w naszej najnowszej historii, tj. obrad Okrągłego Stołu i wyborów parlamentarnych z 4 czerwca 1989 r. Z tym czasem należy wiązać w polskiej polityce narodziny pojęcia: resorty siłowe, choć samo w sobie pojęcie już istniało. W omawianym okresie, zwanym często przejściowym, zarówno resortem Ministerstwa Spraw Wewnętrznych, jak i Ministerstwem Obrony Narodowej kierowali ministrowie w stopniu generalskim, tj. Czesław Kiszczak i Florian Siwicki. Zostali oni usunięci ze swoich stanowisk w lipcu 1990 r., czyli pół roku od rozwiązania Polskiej Zjednoczonej Partii Robotniczej dokonanej 29 stycznia 1990 r. przez uczestników XI Zjazdu.

Konstytucja Rzeczypospolitej Polskiej z dnia 2 kwietnia 1997 r. ${ }^{3}$ mówi o uprawnieniach Prezydenta RP w zakresie bezpieczeństwa i obronności państwa. Przepis art. 126 ust. 2 Konstytucji stanowi, iż „Prezydent Rzeczypospolitej czuwa nad przestrzeganiem Konstytucji, stoi na straży suwerenności i bezpieczeństwa państwa oraz nienaruszalności i niepodzielności jego terytorium”. Ponadto na podstawie przepisu art. 133 Konstytucji, Prezydent jest reprezentantem państwa „w stosunkach zewnętrznych”. Art. 134. ust. 1: „Prezydent Rzeczypospolitej jest najwyższym zwierzchnikiem Sił Zbrojnych Rzeczypospolitej

\footnotetext{
${ }^{3}$ Dz.U. z 1997 r., nr 78, poz. 483.
} 
Polskiej” ust. 2: „W czasie pokoju Prezydent RP sprawuje zwierzchnictwo nad Siłami Zbrojnymi za pośrednictwem Ministra Obrony Narodowej”. Można powiedzieć, że Konstytucja została tak napisana, że w samej treści zawiera „margines ustrojowy” pozwalający na daleko idące interpretacje. Spory i dyskusje na ten temat powinni rozstrzygnąć konstytucjonaliści. Ważne jest to, że narasta świadomość potrzeby zmian w znacznej części społeczeństwa.

Całokształt poczynań obronnych państwa jest zawarty w Strategii Bezpieczeństwa Narodowego Rzeczypospolitej Polskiej ${ }^{4}$. Dokument podpisał Prezydent RP Bronisław Komorowski 5 listopada 2014 r., na wniosek Prezesa Rady Ministrów. Dokument we wstępie stwierdza w pkt 1 „,Strategia w sposób całościowy ujmuje zagadnienia bezpieczeństwa narodowego oraz wskazuje optymalne sposoby wykorzystania na potrzeby bezpieczeństwa wszystkich zasobów pozostających w dyspozycji państwa w sferze obronnej, ochronnej, społecznej i gospodarczej. Kluczową sprawą jest ich właściwa integracja w systemie bezpieczeństwa narodowego....”. Dalej w pkt 2 ,określa potencjał bezpieczeństwa narodowego oraz ocenia środowisko bezpieczeństwa Polski w wymiarze globalnym, regionalnym i krajowym, a także prognozuje jego trendy rozwojowe. Przedstawia działania państwa niezbędne dla osiągnięcia zdefiniowanych interesów i celów oraz wskazuje kierunki i sposoby przygotowania systemu bezpieczeństwa narodowego...” Wstęp kończy: „W przygotowaniu Strategii Bezpieczeństwa Narodowego Rzeczypospolitej Polskiej wykorzystano wyniki Strategicznego przeglądu bezpieczeństwa Narodowego zakończonego w 2012 r. - pierwszego tak szeroko zakrojonego projektu analitycznego odnoszącego się do stanu systemu bezpieczeństwa narodowego i kierunków jego rozwoju...". W Zakończeniu, pkt 152, stawia zadania: „Za realizację postanowień niniejszej strategii odpowiadają ministrowie kierujący działami administracji rządowej, kierownicy urzędów centralnych, wojewodowie, organy samorządu terytorialnego oraz inne podmioty, we właściwościach których pozostają sprawy z zakresu bezpieczeństwa państwa...". Te kierunkowe stwierdzenia zostaną wykorzystane dla prowadzonych w niniejszej pracy kierunków i dociekań oraz badań.

\section{PODMIOTY BIORĄCE UDZIAL W ZARZĄDZANIU BEZPIECZEŃSTWEM PAŃSTWA}

Przedmiotem zainteresowań autorów w tym artykule są wybrane zagadnienia zarządzania w Ministerstwie Obrony Narodowej i Ministerstwie Spraw Wewnętrznych i Administracji, które jak wykazano wcześniej, nazywane są resortami siłowymi. Na rysunku 2 przedstawiono podległość ministerstw.

Studiując literaturę przedmiotu i wsłuchując się w opinię ludzi zajmujących się tematyką z szeroko rozumianą obronnością państwa można powiedzieć, że wojsko rozkazem stoi. Nie zmniejsza to roli i znaczenia innych dokumentów, jak chociażby ustawy z dnia 14 czerwca 1960 r. - Kodeks postępowania administracyjnego 5 .

Rozkaz jest słowem funkcjonującym w Siłach Zbrojnych RP. Jego znaczenie zostało opisane w „Regulaminie ogólnym Sił Zbrojnych Rzeczypospolitej Polskiej” wprowadzonym decyzją nr 188/MON Ministra Obrony Narodowej z dnia 10 czerwca 2009 roku. W omawianym dokumencie w Rozdziale I „Wydawanie i wykonywanie rozkazów” od pkt 15 do pkt 31 - zdefiniowany jest rozkaz. Regulamin jest bardzo „precyzyjny” i w każdym

\footnotetext{
${ }^{4}$ https://www.bbn.gov.pl/ftp/SBN\%20RP.pdf

5 Tekst jedn. Dz.U. z 2017 r., poz. 1257 ze zm.
} 
punkcie jest użyte słowo rozkaz. Dla dalszych rozważań zostanie przytoczony pkt 15, 16, 22,30 i 31 .

„15. Rozkaz jest poleceniem podjęcia określonego działania lub jego zaniechania wydanym służbowo żołnierzowi przez przełożonego(uprawnionego starszego).

16. Ilekroć mowa w regulaminie o rozkazie, należy przez to rozumieć również decyzje wydawane przez przełożonego.

22. Żołnierz po otrzymaniu rozkazu potwierdza to słowem »ROZKAZ«i wykonuje go. Przełożony może sprawdzić zrozumienie rozkazu.

30. Rozkazodawca odpowiada za treść rozkazu oraz dające się przewidzieć skutki jego wykonania, a wykonawca rozkazu - za sposób realizacji.

31. Żołnierz, który wykonując rozkaz wiedział lub godził się na to, że popełnia przestępstwo, ponosi odpowiedzialność karną. Odpowiedzialność karną ponosi również ten, kto taki rozkaz wydał. Ustalenie to obowiązuje niezależnie od treści punktów 26 i 28, których wymowę należy pojmować jako działanie mieszczące się w granicach prawa".

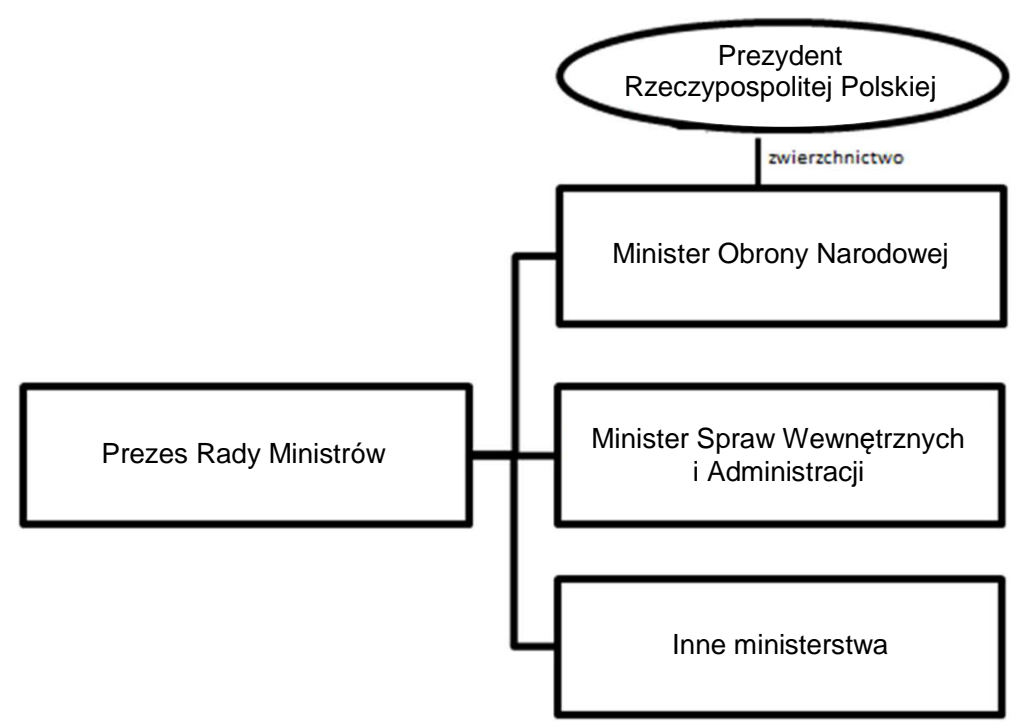

Rys. 2. Podległość resortów siłowych

Źródło: opracowanie własne.

W ustawie z dnia 6 kwietnia 1990 r. o Policji ${ }^{6}$ słowo rozkaz pojawia się w art. 132. ust. 2., 3. pkt 1 i art. 58. ust. 2., 3.

„2. Naruszenie dyscypliny służbowej stanowi czyn policjanta polegający na zawinionym przekroczeniu uprawnień lub niewykonaniu obowiązków wynikających z przepisów prawa lub rozkazów i poleceń wydanych przez przełożonych uprawnionych na podstawie tych przepisów.

\footnotetext{
6 Tekst jedn. Dz.U. z 2017 r., poz. 2067 ze zm.
} 
3. Naruszeniem dyscypliny służbowej jest w szczególności:

1) odmowa wykonania albo niewykonanie rozkazu lub polecenia przełożonego, względnie organu uprawnionego na podstawie ustawy do wydawania poleceń policjantom, z wyłączeniem rozkazów i poleceń, o których mowa w art. 58 ust. 2;

2) Policjant obowiązany jest odmówić wykonania rozkazu lub polecenia przełożonego, a także polecenia prokuratora, organu administracji państwowej lub samorządu terytorialnego, jeśli wykonanie rozkazu lub polecenia łączyłoby się z popełnieniem przestępstwa.

3) O odmowie wykonania rozkazu lub polecenia, o których mowa w ust. 2, policjant powinien zameldować Komendantowi Głównemu Policji z pominięciem drogi służbowej".

Zagadnienia rozkazu i około towarzyszące są opisane przez Witolda Majchrowicza w „Zlecanie zadań służbowych w Policji (zarys problematyki)”7. Rozkaz w wydawnictwie jest definiowany tak jak w Regulaminie ogólnym Sił Zbrojnych RP i ustawie z dnia 6 czerwca 1997 r. - Kodeks karny ${ }^{8}$ - art. 115. § 18. „Rozkazem jest polecenie określonego działania lub zaniechania wydane służbowo żołnierzowi przez przełożonego lub uprawnionego żołnierza starszego stopniem”. W Zarządzeniu nr 30 Komendanta Głównego Policji z dnia 16 grudnia 2013 r. w sprawie funkcjonowania organizacji hierarchicznej w Policji ${ }^{9}$. W rozdziale 1 . Przepisy ogólne $\S 1$. użyte w zarządzeniu określenia oznaczają:

,2) podwładny - policjant lub pracownik Policji zobowiązany z racji zajmowanego stanowiska albo na podstawie odrębnego przepisu lub decyzji uprawnionego organu do podporządkowania się $w$ trakcie pełnienia służby lub wykonywania pracy zarządzeniom, rozkazom i poleceniom lub wytycznym przełożonego;

5) droga służbowa - sposób załatwiania spraw służbowych, polegający na przekazywaniu informacji lub dokumentów albo rzeczy przez podwładnych za pośrednictwem wszystkich kolejnych przełożonych aż do tego, który jest uprawniony do rozstrzygnięcia sprawy, jak również przekazywanie rozkazów, poleceń lub wytycznych od przełożonego uprawnionego do ich wydania, przez kolejnych niższych przełożonych do podwładnego".

Na podstawie analizowanych dokumentów można stwierdzić, że MON dobrze poradziło sobie z pojęciem ,rozkaz” natomiast w MSWiA, zdaniem autorów, należałoby doprecyzować to pojęcie.

\section{NAUKI O BEZPIECZEŃSTWIE - ICH ROLA I ZNACZENIE W ZARZĄDZANIU SYTUACJAMI KRYZYSOWYMI}

W wyniku różnych zagrożeń cywilizacyjnych, których opisywanie nie jest tematem głównym i nie mieści się w ramach artykułu, ze względu na ograniczenia edytorskie autorzy świadomie pominęli. Współczesny świat stanął w obliczu przeciwdziałania skutkom, jakie mogą zostać wygenerowane w przeróżnych płaszczyznach z różną uciążliwością od środowiska naturalnego, ekonomicznego, kulturowego na militarnym kończąc. Mamy do czynienia najpierw z potencjalnym zagrożeniem, następnie z eskalacją i próbą mediacji/przeciw-

\footnotetext{
${ }^{7}$ http://isp.policja.pl/isp/e-czytelnia/1425,Zlecanie-zadan-sluzbowych-w-Policji-Zarys-problematyki.html

8 Tekst jedn. Dz.U. z 2018 r., poz. 1600.

${ }^{9}$ Dz. Urz. KGP z 2013 r., poz. 99.
} 
działania w celu zażegnania konfliktu/destrukcji. Jeżeli wymienione stopnie „narastania” nie zostaną na wymienionych poziomach zażegnane dojdzie do rozwiązań naturalnych lub siłowych zarówno ze strony natury (powódź), jak i rozwiązań (konflikt zbrojny, tłumienie manifestacji, ograniczonej ewakuacji), jakimi dysponują resorty siłowe. Nikt już dzisiaj nie powie, że za bezpieczeństwo odpowiadają tylko wybrane ministerstwa. Zajmowanie się bezpieczeństwem człowieka stanowi wezwanie dla decydentów i polityków. Do przełomu wieku bezpieczeństwo kojarzone było w większości przez Polaków z resortami siłowymi. Wybrane uczelnie resortów siłowych zestawiono w tabeli 1.

Tabela 1. Wybrane uczelnie mundurowe

\begin{tabular}{|c|c|}
\hline Ministerstwo Obrony Narodowej & $\begin{array}{l}\text { Akademia Sztuki Wojennej w Warszawie kształci oficerów } \\
\text { na potrzeby dowództw, sztabów, instytucji wojskowych } \\
\text { i cywilnych związanych z obronnością państwa. Młodzież } \\
\text { cywilną przygotowuje do zadań publicznych, szczególnie } \\
\text { w zakresie bezpieczeństwa narodowego oraz systemu rea- } \\
\text { gowania kryzysowego }{ }^{10} \text {. }\end{array}$ \\
\hline \multirow[t]{2}{*}{$\begin{array}{l}\text { Ministerstwo Spraw Wewnętrznych } \\
\text { i Administracji }\end{array}$} & $\begin{array}{l}\text { Wyższa Szkoła Policji w Szczytnie jest jednostką organi- } \\
\text { zacyjną Policji w rozumieniu ustawy z dnia } 6 \text { kwietnia } \\
1990 \text { r. o Policji. Zgodnie z ustawą z dnia } 27 \text { lipca } \\
2005 \text { r. - Prawo o szkolnictwie wyższym, jest uczelnią } \\
\text { służb państwowych nadzorowaną przez ministra właści- } \\
\text { wego do spraw wewnętrznych (posiadającą osobowość } \\
\text { prawną). }\end{array}$ \\
\hline & $\begin{array}{l}\text { „Szkoła Główna Służby Pożarniczej jest publiczną uczelnią } \\
\text { służb państwowych, kształcącą i wychowującą strażaków } \\
\text { Państwowej Straży Pożarnej, funkcjonariuszy innych służb } \\
\text { i straży oraz osoby cywilne w zakresie bezpieczeństwa } \\
\text { powszechnego i ochrony ludności. SGSP została utwo- } \\
\text { rzona rozporządzeniem Rady Ministrów z dnia } 18 \text { stycznia } \\
1982 \text { r. w sprawie utworzenia Szkoły Głównej Służby } \\
\text { Pożarniczej11, działa na podstawie ustawy z dnia } 27 \text { lipca } \\
2005 \text { r. - Prawo o szkolnictwie wyższym }{ }^{12} \text { oraz statutu. } \\
\text { SGSP jest jednocześnie jednostką organizacyjną Państwo- } \\
\text { wej Straży Pożarnej, działającą na podstawie ustawy z dnia } \\
24 \text { sierpnia } 1991 \text { r. o Państwowej Straży Pożarnej }{ }^{13} \text {. }\end{array}$ \\
\hline
\end{tabular}

Źródło: opracowanie własne.

Rozporządzenie Ministra Nauki i Szkolnictwa Wyższego pozwoliło w roku akademickim 2011/2012 nadać nową jakość studiów wyższych. Nauki o bezpieczeństwie wykładane są na uczelniach o różnym profilu. Każda uczelnia nadaje tym naukom swoją „specyfikę" na tyle silną, aby była utożsamiana z uczelnią. Analizując ofertę edukacyjną i programy nauczania uczelni można zauważyć, różnice w podejściu do zagadnień bezpieczeństwa

\footnotetext{
${ }^{10}$ Ustawa z dnia 20 maja 2016 r. o utworzeniu Akademii Sztuki Wojennej (Dz.U. z 2016 r., poz. 906).

${ }^{11}$ Dz.U. nr 3, poz. 21.

${ }^{12}$ Dz.U. nr 164, poz. 1365 ze zm.

${ }^{13}$ Dz.U. z 2009 r., nr 12, poz. 68 ze zm.
} 
uczelni uniwersyteckich, politechnicznych i wyższych szkół, jednak wszystkie z nich mówią o zaletach podjęcia studiów na kierunku bezpieczeństwo:

- unikatowe przedmioty,

- profesjonalna i specjalistyczna praktyka studencka/zawodowa,

- specjalistyczne przedmioty,

- wiedza dostępna dla nielicznych.

Zatrudnienie na stanowiskach pracy związanych z szeroko rozumianą obronnością państwa i bezpieczeństwem:

- administracja państwowa i samorządowa,

- jednostki służb mundurowych,

- przemysł obronny,

- organizacje publiczne,

- agencje ochrony, detektywistyczne.

Rynek z branży bezpieczeństwa potrzebuje specjalistów interdyscyplinarnych. Miejsce możliwego zatrudnienia absolwenta kierunku bezpieczeństwo realizowanych na uczelniach niemundurowych przedstawiono na osi umieszczonej w tabeli 2.

Tabela 2. Miejsce absolwenta kierunku bezpieczeństwo w obszarze potencjalnego zatrudnienia

\begin{tabular}{|c|c|c|}
\hline$-\infty$ Bezpieczeństwo miękkie & Bezpieczeństwo & $+\infty$ Bezpieczeństwo twarde \\
\hline Pedagogika & \multirow{7}{*}{$\begin{array}{l}\text { Studenci kierunku } \\
\text { bezpieczeństwo }\end{array}$} & Policja \\
\hline Psychologia & & Straż graniczna \\
\hline Socjologia & & Zarządzanie kryzysowe \\
\hline Ekonomia & & Organizacje paramilitarne \\
\hline Zarządzanie Administracja & & Straże miejskie i gminne \\
\hline Ekologia & & Ochrona \\
\hline $\begin{array}{l}\text { Ochrona i kształtowanie } \\
\text { środowiska }\end{array}$ & & Siły Zbrojne \\
\hline
\end{tabular}

Źródło: opracowanie własne.

Schemat jest niepełny, ale na pierwszy rzut oka widać, że bezpieczeństwo zarówno miękkie, jak i twarde wzajemnie się przeplata, stąd obawy autorów czy bezpieczeństwo może być wyalienowane $\mathrm{z}$ nauk społecznych (np. zarządzanie bezpieczeństwem żywnościowym). Wspomniane ministerstwa siłowe mają resortowe szkolnictwo, które zapewnia im profesjonalnie wykształcone kadry. Rodzi się pytanie, czy absolwent bezpieczeństwa może być doskonałym rozwiązaniem, zapewniającym obsadę na stanowiskach niewysoko specjalizowanych? Bezpieczeństwo umownie nazwane bezpieczeństwem miękkim kształci w wymienionych specjalnościach również w aspekcie zagrożeń. Te zagrożenia rozumiane są jako niebezpieczeństwo. Bezpieczne zarządzanie obok bezpieczeństwa ekologicznego (energetycznego, żywnościowego, społecznego) to często używane terminy. Kryje się tu jednak pewne niebezpieczeństwo. W takiej konfiguracji słów w zdaniu słowo bezpieczne staje się ważniejsze, a to powinno dać wiele do myślenia. Szczególnie tym decydentom, którzy zajmują się tymi dziedzinami. Temu rozróżnianiu pojęć poświęcone zostaną badania w aspekcie zarządzania elementami bezpieczeństwa w resortach umownie zwanych siłowymi. 


\section{BADANIA WLASNE}

Nauki o bezpieczeństwie, choć nie nowe, w ostatnim dziesięcioleciu zostały w szkolnictwie wyższym mocno rozpowszechnione. Absolwent studiujący kierunek bezpieczeństwo na początku jest przekonany, że będzie zatrudniony w instytucjach zapewniających poczucie bezpieczeństwa społeczeństwu, do których można z całą pewnością zaliczyć zarządzanie kryzysowe. Zarządzanie kryzysowe, to ta część bezpieczeństwa, w którym jak w soczewce musi się skupić współdziałanie wszystkich służb odpowiedzialnych za jego utrzymanie. Nie sposób sobie wyobrazić prowadzenie jakiejkolwiek akcji bez udziału Policji, Państwowej Straży Pożarnej, Sił Zbrojnych czy administracji państwowej. Jak już zostało opisane, w każdej instytucji istnieją procedury, w których używa się słów zarządzających. Ankieta została skonstruowana w taki sposób, że zawiera słowa umożliwiające zarządzanie, występujące w organach państwa. Słowa ,zarządzające” pochodzą z następujących dokumentów:

- Zarządzenie nr 30 Komendanta Głównego Policji z dnia 16 grudnia 2013 r. w sprawie funkcjonowania organizacji hierarchicznej w Policji;

- Decyzja nr 385/MON Ministra Obrony Narodowej z dnia 17 grudnia 2013 r. w sprawie wprowadzenia do użytku ,Instrukcji o zasadach pracy biurowej w resorcie obrony narodowej" 14 ;

- Obwieszczenie Marszałka Sejmu Rzeczypospolitej Polskiej z dnia 8 czerwca 2017 r. w sprawie ogłoszenia jednolitego tekstu ustawy - Kodeks postępowania administracyjnego ${ }^{15}$.

Zadaniem ankietowanych było postawienie znaku X przy dokumencie, który obowiązuje w resortach siłowych i organach administracji państwowej. Postawiono też jedno pytanie, które dotyczyło rozumienia pojęcia, co oznacza zarządzanie kryzysowe? Ankietę kończy pytanie otwarte, w którym proszono o zdefiniowanie słowa rozkaz i rozumienie pojęcia zwierzchnik Sił Zbrojnych. Głównym celem przeprowadzonych badań była ocena poziomu wiedzy i umiejętności studentów szkoły wyższej, kierunek bezpieczeństwo, w zakresie rozpoznawania słów, które służą kierowaniu siłami i środkami państwa w czasie sytuacji kryzysowej. Badania zestawiono na wykresach.

Na wykresie 1 przedstawiono populację biorącą udział w badaniu.

Badania przeprowadzono 3 stycznia 2018 r. w szkole wyższej na kierunku bezpieczeństwo studia dzienne licencjackie semestr V. W badaniu wzięły udział 22 kobiety i 13 mężczyzn. Badanie było dobrowolne, nikt nie odmówił wypełniania ankiety. Prawie 2/3 grupy stanowiły kobiety.

Jak pokazuje wykres 2, zdecydowana większość mężczyzn wybrała odpowiedź I. Tylko jeden mężczyzna zdecydował się na zakreślenie odpowiedź IV. U kobiet zastanawiający jest duży rozrzut odpowiedzi i tak na pytanie I - 11, II - 3, III - 2, IV - 6. Badania, zdaniem autorów, w grupie kobiet powinny zostać powtórzone na podobnej populacji.

\footnotetext{
${ }^{14}$ Dz. Urz. MON z 2013 r., poz. 338

${ }^{15}$ Dz.U. z 2017 r., poz. 1257.
} 


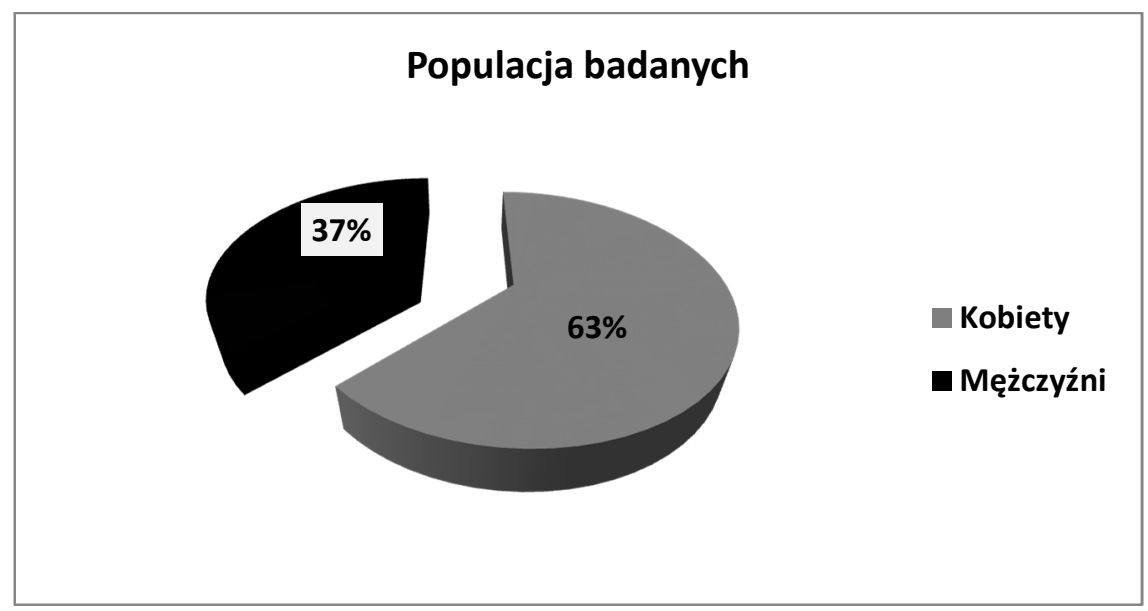

Wykres 1. Populacja badanych

Źródło: opracowanie własne.

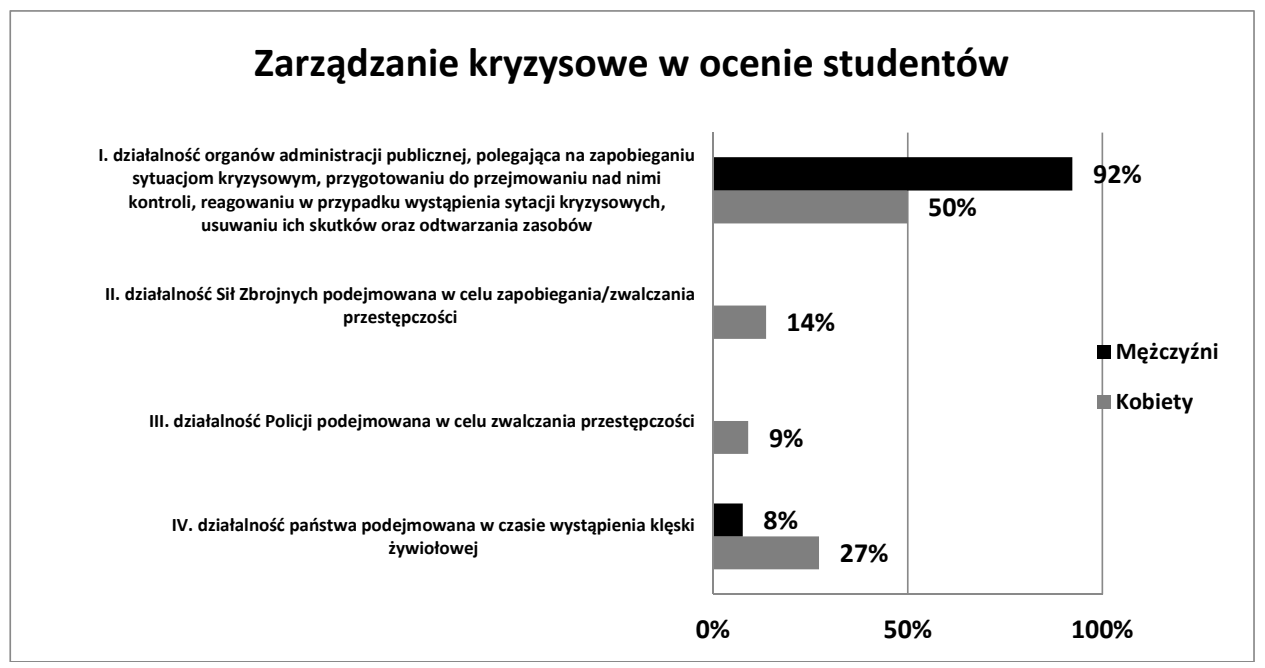

Wykres 2. Znajomość pojęcia zarządzanie kryzysowe

Źródło: opracowanie własne.

W następnym pytaniu ankietowani mogli zakreślić więcej niż jedną odpowiedź. Jak obrazuje wykres 3 najlepiej jest rozpoznawalny „rozkaz”, został on przypisany tylko do resortów siłowych. Słabo rozpoznawalne są: komórka organizacyjna, jednostka organizacyjna, strona, ugoda i wznowienie postępowania. 


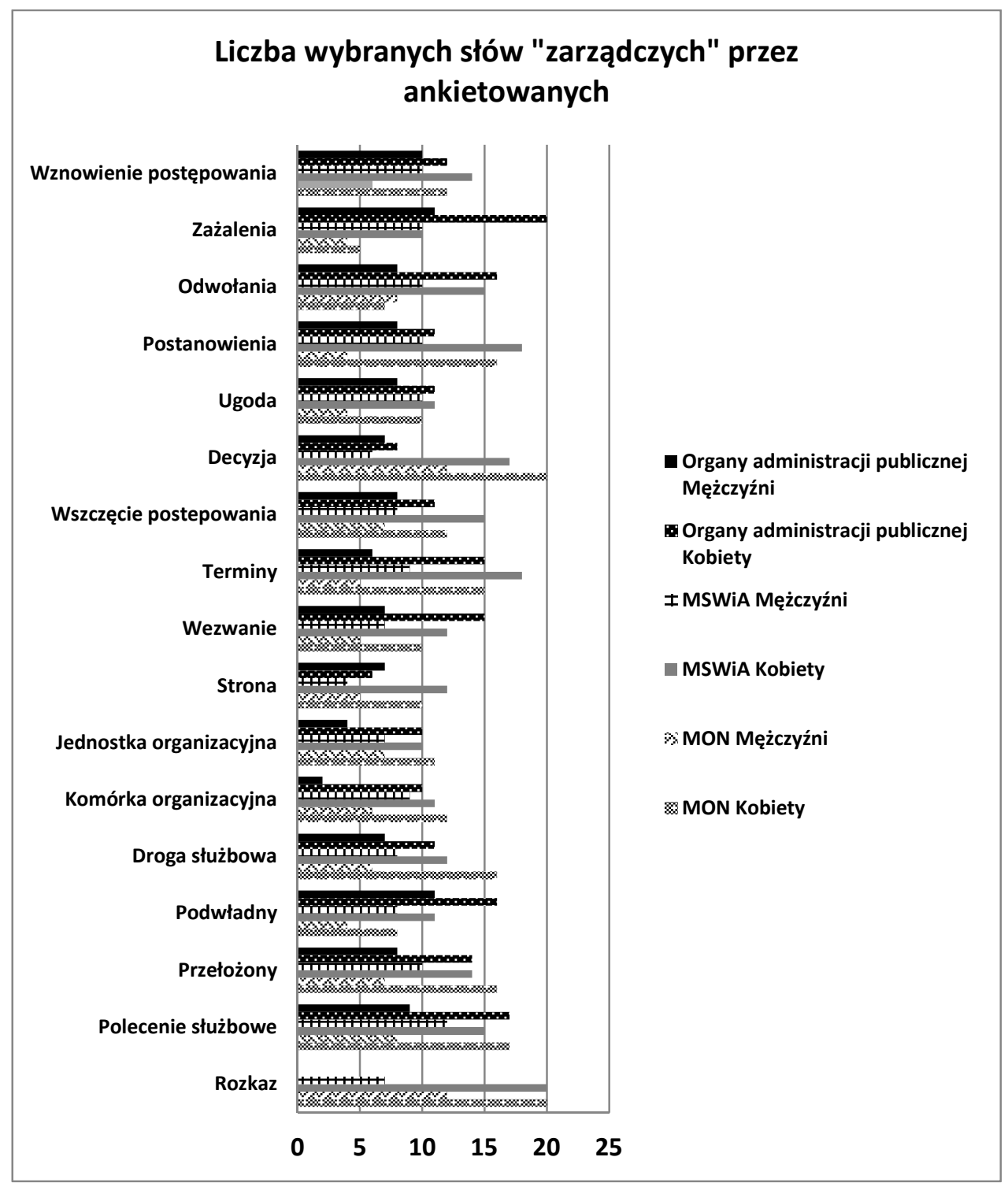

Wykres 3. Liczba wybranych słów na poszczególne terminy podane w ankiecie. Źródło: opracowanie własne.

Na wykresach 4 i 5 przedstawiono odpowiedzi na pytania otwarte, które brzmiały: co oznacza słowo rozkaz i co oznacza pojęcie zwierzchnictwo nad Siłami Zbrojnymi. Pytania otwarte oceniono metodą sędziów niezależnych, którymi byli komandorowie rezerwy z 30- i 40-letnim stażem służby. 


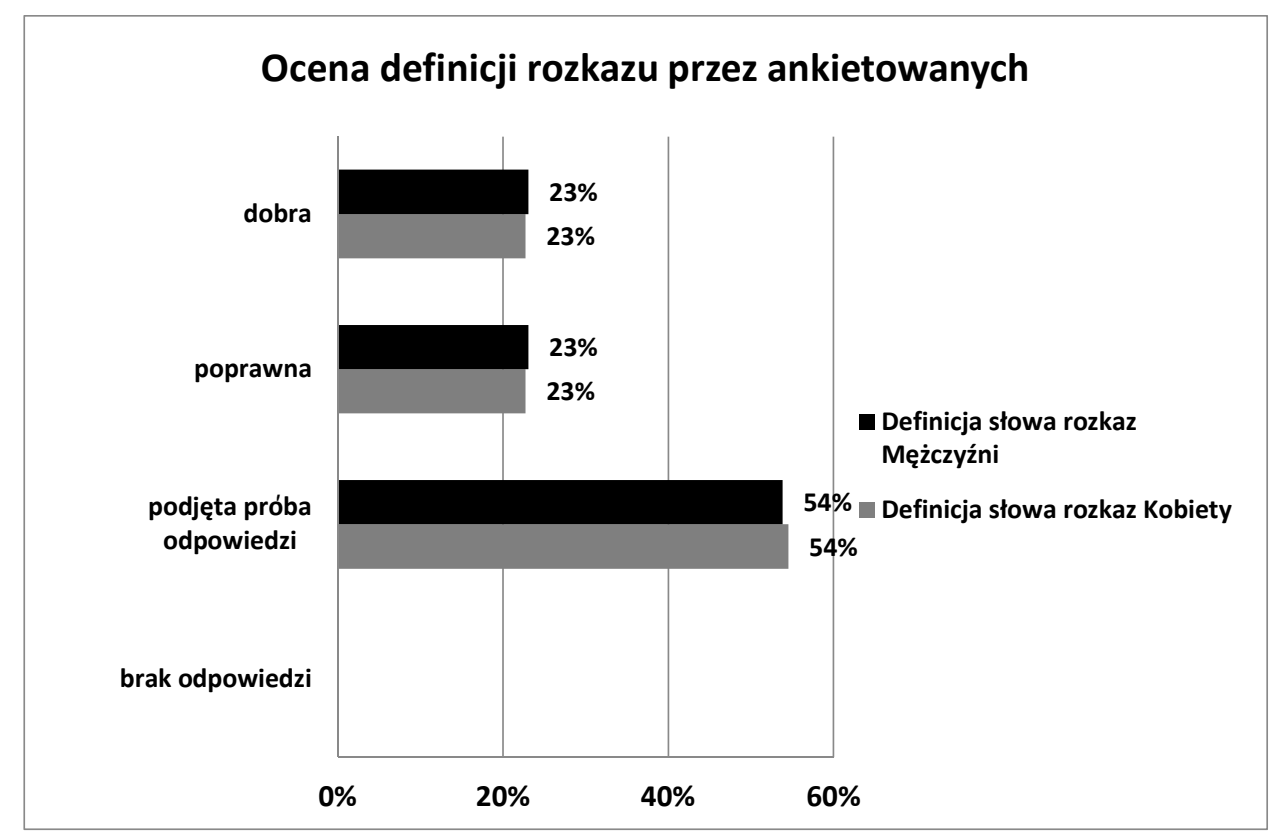

Wykres 4. Ocena definicji rozkazu

Źródło: opracowanie własne.

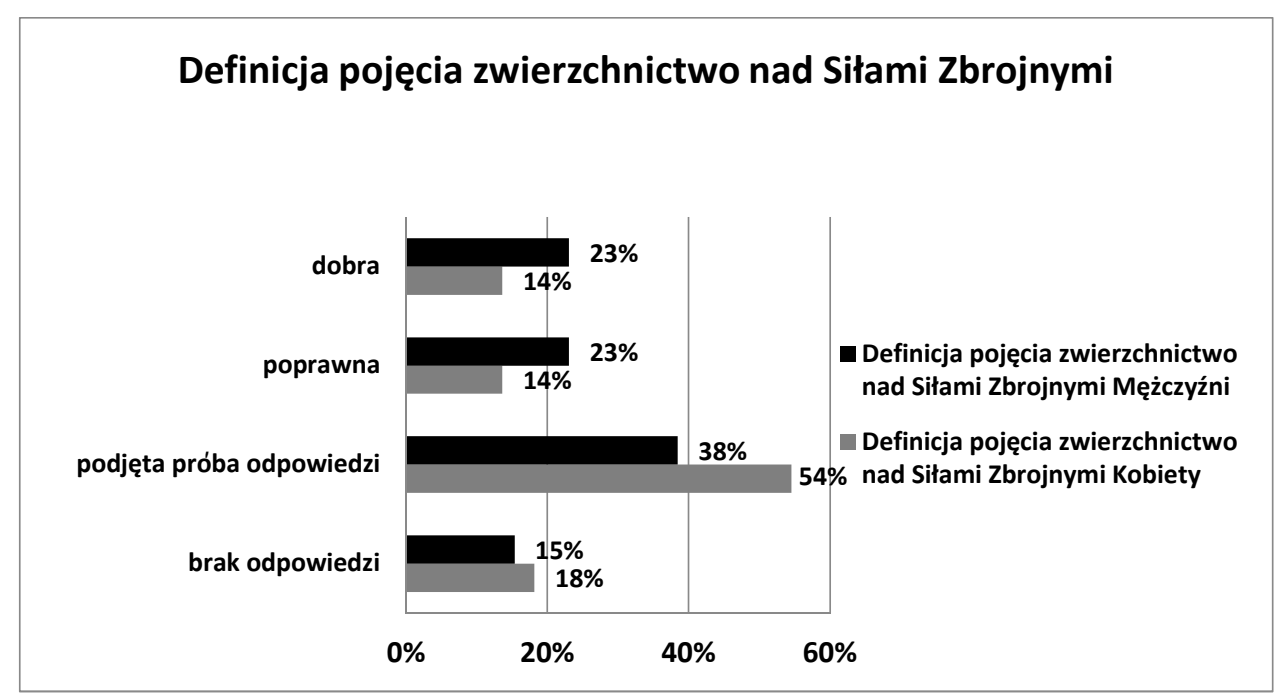

Wykres 5. Ocena pojęcia zwierzchnictwa nad Siłami Zbrojnymi Źródło: opracowanie własne. 
Zdecydowana większość respondentów podjęła jedynie próbę odpowiedzi związaną $\mathrm{z}$ oceną definicji rozkazu, ponad $50 \%$. W tej sytuacji cieszyć może fakt, że nie odnotowano braku odpowiedzi. Zastanawiająca jest niewątpliwie kwestia, że studenci kierunku bezpieczeństwo tylko $\mathrm{w}$ niewielkim stopniu potrafią wskazać dobrą definicję pojęcia rozkaz $(23 \%)$.

W ocenie pojęcia zwierzchnictwo nad Siłami Zbrojnymi niepokojące jest niepodjęcie udzielenia odpowiedzi (15\% mężczyźni; 18\% kobiety). Dobra i poprawna ocena wystąpiła w małym stopniu i rozłożyła się proporcjonalnie: kobiety - 14 i 14\%, natomiast mężczyźni 23 i 23\%. Niewątpliwie nie jest to wynik zadowalający. Widoczna jest na przedstawionym wykresie chęć badanych do udzielenia odpowiedzi, ale to za mało, aby wykazać się podstawową wiedzą na temat zwierzchnictwa nad Siłami Zbrojnymi.

\section{WNIOSKI KOŃCOWE}

Potrafimy cieszyć się bezpieczeństwem szczególnie wtedy, gdy jest efektywne, jednak większość z nas nie potrafi go zdefiniować. Najbardziej bliskie jest nam bezpieczeństwo, które opisuje „moje” siedlisko wyalienowane z tego ogólnego naturalnego jak i tego utechnicznionego. Może jest tu coś z powiedzenia: „Szlachcic na zagrodzie równy wojewodzie”. Jednocześnie potrafimy jakoś współczuć innym poszkodowanym. Jak długo pamiętamy o tragedii bliskich i anonimowych poszkodowanych, tej odpowiedzi musimy szukać we własnym i społecznym sumieniu. W naszej narodowej społeczności mocno zakorzeniło się obiegowe poczucie bezpieczeństwa dotyczące mojego ego, to dalsze mnie zazwyczaj nie dotyczy, w znaczeniu nie odczuwam skutków jego oddziaływania i lub rażenia. Trudno jest modyfikować swoje poglądy, które zaakceptowaliśmy, jednym słowem przyzwyczailiśmy się do nich i w obliczu nowych niepodważalnych dowodów tworzących nową rzeczywistość nie akceptujemy zmian. W dalszej konsekwencji rodzi się w nas wielki emocjonalny dyskomfort. Tak opisane zachowanie jest już definicją błędu potwierdzenia (ang. confirmation bias) z bardzo silnym mechanizmem kognitywnym. Językoznawstwo kognitywne zakłada, że język jest częścią ludzkiego funkcjonowania poznawczego i narzędziem komunikowania. W obszarze zarządzania bezpieczeństwem zaczął „działać” mechanizm tworzenia amalgamatów pojęciowych. Współczesnemu odbiorcy najprościej jest to przedstawić jako bryłę z drukarki 3D, w której to w sposób niezwykle plastyczny scala się elementy różnych pojęć umożliwiając szczególnie tym, co na co dzień nie interesują się zagadnieniem, dotknięcie aspektów prawie że organoleptycznie. Wirus komputerowy to przykład amalgamatu pojęciowego i jest w swojej treści ogłoszeniem alarmu.

Badania pozwalają na sformułowanie wniosków:

1. Badania pilotażowe umacniają autorów w przekonaniu, że warto przeprowadzić badania na młodzieży akademickiej studiującej w akademii, uniwersytecie, uniwersytecie technicznym i politechnice w celu zbadania, co wnosi profil uczelni do kierunku bezpieczeństwo?

2. Pogodzenie interesów resortów siłowych i gospodarki narodowej jest wezwaniem dla decydentów.

3. Programy nauczania wymagają ,przeglądu i dopracowania” pod kątem kompatybilności słownictwa umożliwiającego sprawne kierowanie. 


\section{PRAWODAWSTWO}

1. Konstytucja Rzeczypospolitej Polskiej z dnia 2 kwietnia 1997 r. (Dz.U. z 1997 r., nr 78, poz. 483).

2. Ustawa z dnia 14 czerwca 1960 r. - Kodeks postępowania administracyjnego (tekst jedn. Dz.U. z 2017 r., poz. 1257 ze zm.).

3. Ustawa z dnia 6 kwietnia 1990 r. o Policji (tekst jedn. Dz.U. z 2017 r., poz. 2067 ze zm.).

4. Ustawa z dnia 24 sierpnia 1991 r. o Państwowej Straży Pożarnej (Dz.U. z 2009 r., nr 12, poz. $68 \mathrm{ze} \mathrm{zm.).}$

5. Ustawa z dnia 6 czerwca 1997 r. - Kodeks karny (tekst jedn. Dz.U. z 2018 r., poz. 1600).

6. Ustawa z dnia 27 lipca 2005 r. - Prawo o szkolnictwie wyższym Dz.U. nr 164, poz. 1365 ze zm.

7. Ustawa z dnia 20 maja 2016 r. o utworzeniu Akademii Sztuki Wojennej (Dz.U. z 2016 r., poz. 906).

8. Rozporządzenie Rady Ministrów z dnia 18 stycznia 1982 r. w sprawie utworzenia Szkoły Głównej Służby Pożarniczej (Dz.U. nr 3, poz. 21).

9. Rozporządzenie Ministra Nauki i Szkolnictwa Wyższego z dnia 8 sierpnia 2011 r. w sprawie obszarów wiedzy, dziedzin nauki i sztuki oraz dyscyplin naukowych i artystycznych (Dz.U. z 2011 r., nr 179, poz. 1065).

10. Decyzja nr 385/MON Ministra Obrony Narodowej z dnia 17 grudnia 2013 r. w sprawie wprowadzenia do użytku ,Instrukcji o zasadach pracy biurowej w resorcie obrony narodowej” (Dz. Urz. MON z 2013 r., poz. 338).

11. Obwieszczenie Marszałka Sejmu Rzeczypospolitej Polskiej z dnia 8 czerwca 2017 r. w sprawie ogłoszenia jednolitego tekstu ustawy - Kodeks postępowania administracyjnego (Dz.U. z 2017 r., poz. 1257).

12. Zarządzenie nr 30 Komendanta Głównego Policji z dnia 16 grudnia 2013 r. w sprawie funkcjonowania organizacji hierarchicznej w Policji (Dz. Urz. KGP z 2013 r., poz. 99).

\section{NETOGRAFIA}

1. http://isp.policja.pl/isp/e-czytelnia/1425,Zlecanie-zadan-sluzbowych-w-Policji-Zarys-problematyki.html.

2. http://prawo.sejm.gov.pl/isap.nsf/DocDetails.xsp?id=WDU20170001257.

3. http://www.akademia.mil.pl/historia-i-zadania/miedzy-tradycja-a-przyszloscia_aszwoj.html.

4. https://www.bbn.gov.pl/ftp/SBN\%20RP.pdf.

5. https://www.wspol.edu.pl/g/uczelnia/o-szkole.

6. isp.policja.pl/download/12/1250/zlecanie.pdf.

7. Platon - biografia, http://www.ptta.pl/pef/pdf/p/platon.pdf.

8. Rząd Tadeusza Mazowieckiego - między PRL a III RP, http://muzhp.pl/pl/c/1381/rzad-tadeusza-mazowieckiego-miedzy-prl-a-iii-rp.

9. Schematyczna ilustracja fotosyntezy, https://www.google.pl/search?q=proces+fotosyntezy\& client=firefox-b-ab\&dcr=0\&tbm=isch\&source=iu\&ictx=1\&fir=FWaLRfEIgA7uJM $\%$ 253A\%252Cs8jDVUIS0wDrzM\%252C_\&usg=_juzK4Q2HJPF-8AVE0XbAmXdfGhs\% 3D\&sa=X\&ved=0ahUKEwjv4uGHo4TYAhUGU1AKHfCQCuoQ9QEITDAH\#imgrc= xvgH9gFg7HAtHM. 
10. Strategia Bezpieczeństwa Narodowego Rzeczypospolitej Polskiej 2014, https://www.bbn. gov.pl/ftp/SBN\%20RP.pdf.

11. strzelec.pwsz.nysa.pl/wp-content/uploads/2012/05/regulamin_ogolny.pdf.

12. Szkoła Główna Służby Pożarniczej, http://www.sgsp.edu.pl/uczelnia/group/o-uczelni/\#listgroup-237790.

\section{MANAGEMENT IN DEPARTMENTS CONNECTED WITH STATE DEFENSE ACCORDING TO THE OPINIONS OF SECURITY STUDENTS}

Contemporary state management by its structures using human resources is a challenge for the elite leaders during geopolitical uncertainty and economic cycles. The key factor in building a modern state is the staff as its inseparable element. As predicted by specialists in this area, it is necessary to anticipate the possibility of solving socio-political and economic problems that may yet occur, and whose course as well as the potential threats are still difficult to describe, let alone define. All this with new threats emerging in the sphere of cyberspace as dominant in present and future times. In the history of the state's continuity, many normative acts have been created, which are designed to describe the framework of its functioning - they are constantly subject to change. In brief, the legal acts regulating the examined problem will be presented, with particular emphasis on the "force" ministries directly related to the security of the state. Linguistic forms, conceptual phrases (decision, order, service order) will be described, not all of them are typical only for these ministries. State security is created by the entire national economy. The article aims at an encyclopedic presentation of these concepts only because of the size of the publication, which is still large enough to show the purpose of the article. However, their understanding will be examined on the population of students taking security courses. As the authors predict, the research results may be used to confirm the validity of teaching plans or their modifications with the use of innovative solutions.

Keywords: management, security, power departments.

DOI: $10.7862 /$ rz.2018.hss.57

Przestano do redakcji: marzec $2018 r$.

Przyjęto do druku: wrzesień 2018 r. 
